\title{
EXPLORE
}

\section{Penerapan Logical Unit Number (LUN) Pada Drobo Virtual Storage Dengan Metode Network Development Life Cycle (NDLC)}

\author{
M. Hadi Prayitno, Hendarman Lubis \\ Program Studi Teknik Informatika, Fakultas Teknik \\ Universitas Bhayangkara Jaya \\ Bekasi, Indonesia \\ hadi.prayitno@dsn.ubharajaya.ac.id, hendarman.lubis@dsn.ubharajaya.ac.id
}

\begin{abstract}
In line with the development of a company that is increasingly large as the development of information technology is used, which in turn will also affect the provision of storage devices that can display data that operate for 24 hours. This is what drives PT. Pertiwi Agung, which will currently develop its business, even though it currently has a market share around Southeast Asia. The company must be able to store all the data which can certainly be very large. For this reason, a media is needed, the media is Virtual Storage which is managed by Drobo, an external storage device that relies on a Logical Unit Number that can identify all equipment used. To be more targeted, the process of implementing the Logical Unit Number in Virtual Storage uses the Network Development Life Cycle (NDLC) method. The result of applying the Logical Unit Number is that this considerable amount of data can be read and integrated, even though the storage media is spread in several places.

Keywords: Virtual Storage, Logical Unit Number, Drobo, NDLC
\end{abstract}

Keywords : Virtual Storage, Logical Unit Number, Drobo, NDLC

Abstrak-Sejalan dengan perkembangan perusahaan yang semakin besar seiring pekembangan teknologi informasi yang digunakan, yang selanjutnya akan pula berpengaruh pada penyediaan alat penyimpanan yang dapat menampng data yang beroperasi selama 24 jam. Hal ini yang mendorong PT. Pertiwi Agung, yang saat ini akan mengembangkan usahanya, meski saat ini memiliki pangsa pasar di sekitar Asia Tenggara. Perusahaan harus dapat menyimpan seluruh data yang sudah dapat dipastikan akan sangat besar. Untuk itu diperlukan sebuah media, media itu adalah Virtual Storage yang di atur oleh Drobo, sebuah alat penyimpanan eksternal dengan mengandalkan Logical Unit Number yang dapat mengidentifikasikan seluruh peralatan yang digunakan. Agar lebih terarah, maka proses implementasi Logical Unit Number pada Virtual Storage ini mengunakan metode Network Development Life Cycle (NDLC).Hasil dari penerapan Logical Unit Number ini adalah data yang cukup banyak ini dapat terbaca dan terintegrasi, meski media penyimpanannya tersebar di beberapa tempat.

\section{Kata Kunci: Virtual Storage, Logical Unit Number, Drobo, NDLC}

\section{Pendahuluan}

PT. Pertiwi Agung adalah salah satu perusahaan farmasi yang sedang memperluas jajaran produknya dengan obat-obatan sintetis dan obat-obatan herbal dan salah satu industri farmasi dengan pertumbuhan tercepat di Indonesia dan perusahaan juga tertarik untuk memperluas posisinya ke pasar global, terutama Nigeria, Malaysia, Singapura, Mongolia, dan daerah disekitarnya.

PT. Pertiwi Agung memiliki banyak department diantarnya adalah Quality Control (QC) Department dan Research and Development (RND) Department. Department tersebut memiliki beberapa unit komputer yang dipergunakan untuk analis suatu produk, baik itu untuk produk rilis ataupun kelayakan produk. Setiap unit komputer yang diperuntukan analisa memiliki 24 (dua puluh empat) jam operasional. Hal ini sangat membutuhkan pemeliharaan terutama ketersiaan media penyimpan yang berkelanjutan.

Perusahaan sangat membutuhkan suatu infrastruktur Virtual Storage Server guna menunjang operasionalnya terutama untuk prnyimpanan data QC-RND Analis, maka dari itu dibutuhkanlah suatu pengalokasian atau konfigurasi Virtual Storage Logical Unit Number Drobo SAN(Storage Area Network) yang terstruktur guna mengatasi masalah ketersediaan media penyimpanan ini.

Guna lebih berfokus pada permasalahan yang dihadapi, maka diperlukan pedoman untuk memberi arah 
yang tepat sesuai dengan kebutuhan perusahaan, terutama dibidang jaringan bisnis, disusunlah Network Development Live Cycle (NDLC)

NDLC memiliki beberapa tahap meliputi Analysis, Design, Simulation Prototyping, Implementation, Monitoring, dan Management. Pada penelitian ini tahap pada metode NDLC yang digunakan hanya sampai tahap Simulation

\section{Dasar Teori}

Jurnal penelitian yang membahas tentang Virtual Storage dengan judul "Implementasi Virtual Data Storage menggunakan Openfiler dengan Protokol iSCSI pada Kantor Camat Jatinegara Jakarta" judul penelitian ini hampir berkaitan dengan penelitian yang akan penulis buat yaitu Virtual Storage, pada penelitian ini memiliki masalah yang sama yaitu pembuatan virtual storage iSCSI, dimana masih ada kekurangan pada jurnal tersebut yakni tidak membuat virtual storage ke enduser (Client) [12]

Jurnal penelitian yang membahahas tentang Virtual Storage SAN/NAS dengan judul "A Study Paper on Storage Are Network Problem-Solving Issue" judul penelitian ini berkaitan dan menjadi acuan penulis untuk merangcang pemanfaatan suatu SAN atau NAS sesuai kondisi yang dibutuhkan yakni implementasi virtual storage secara langsung ke enduser (PC- User)[14].

\section{a. Jaringan Komputer}

Model komputer yang melayani seluruh tugas tugas komputasi suatu organisasi telah di ganti oleh sekumpulan komputer berjumlah banyak yang terpisah - pisah akan tetapi saling berhubungan disebut jaringan komputer[2].

Menurut O'Brien (2011) lebih spesifik menyatakan bahwa, "Jaringan adalah sebuah jaringan komputer terdiri atas media komunikasi peralatan - peralatan, software yang dibutuhkan untuk menghubungkan dua atau lebih sistem komputer dan peralatan. Jaringan merupakan sistem interkoneksi saluran komputer, terminal, dan komunikasi dan perangkat." Jaringan berarti saling berhubungan atau saling rantai, kelompok, atau sistem[13].

b. Drobo

Drobo adalah serangkaian perangkat penyimpanan eksternal untuk komputer. Mereka terbuat dari berbagai jenis termasuk DAS, SAN, dan peralatan NAS yang dibuat oleh Drobo, Inc. Perangkat Drobo saat ini dapat menampung hingga empat, lima, delapan, atau dua belas 3,5 "atau 2,5" Serial ATA atau Serial Attached SCSI hard disk drive dan terhubung dengan komputer atau jaringan melalui USB 2.0, USB 3.0, FireWire 800, eSATA, Gigabit Ethernet atau Thunderbolt. Perangkat Drobo terutama dirancang untuk memungkinkan pemasangan dan penghapusan drive hard disk tanpa memerlukan migrasi data manual, dan juga untuk meningkatkan kapasitas penyimpanan unit tanpa downtime.

Perusahaan Drobo, Inc. mengubah namanya dari Data Robotics pada tahun 2011 karena keakraban dengan nama Drobo (yang sampai saat itu hanya nama lini produk mereka) jauh melebihi nama Data Robotics. Drobo, Inc. bergabung dengan Connected Data, Inc. pada Juni 2013, dengan perusahaan baru yang menggunakan nama Connected Data. Pada Mei 2015, Drobo diakuisisi oleh grup investasi yang terdiri dari eksekutif teknologi berpengalaman dan mengubah nama perusahaan menjadi Drobo, Inc [3].

\section{c. Logical Unit Number}

Logical Unit Number (LUN) adalah nomor yang digunakan untuk mengidentifikasi unit logis yang berkaitan dengan penyimpanan komputer. Unit logis adalah perangkat yang ditangani oleh protokol dan terkait dengan saluran Small Computer Systems Interface (SCSI), Internet Small Computer Systems Interface SCSI (SSCSI) dan antarmuka lain yang sebanding [6]. Storage Networking Protocol Fundamentals). LUN adalah pusat pengelolaan array penyimpanan blok dalam jaringan area penyimpanan $(S A N)$. Menggunakan LUN dapat menyederhanakan pengelolaan sumber daya penyimpanan karena hak akses dan kontrol dapat ditetapkan melalui pengidentifikasi logis.

LUN sangat penting untuk mengelola blok penyimpanan blok dari SAN. LUN biasa digunakan dengan komponen apa pun yang mendukung proses read/mrite. LUN umumnya digunakan untuk cakram logis yang dihasilkan pada $S A N$. Istilah LUN dimulai dari protokol SCSI dan menyediakan metodologi untuk mengidentifikasi disk drive tertentu dalam komponen biasa seperti arraydisk. Seringkali, istilah LUN digunakan dalam referensi ke diskdrive yang sebenarnya, yang tidak akurat secara teknis. Selain itu, LUN dapat merujuk ke saluran akses input/output dalam bahasa pemrograman yang dipilih. Hari ini, Luns ditemukan tidak hanya pada disk drive, tetapi juga pada partisi virtual atau pada volume $R A I D$ (Redundant Array of Inexpensive Disks) yang menggunakan beberapa drive. Pengontrol akses host ke LUN untuk menciptakan keamanan data dan integritas data berbasis switch, serta mengelola sumber daya $S A N$ yang dapat diakses oleh host yang ditentukan. LUN umumnya diatur pada lapisan switch untuk meningkatkan keamanan di jaringan serta membatasi akses host ke target SCSI yang ditunjuk pada LUN tersebut. Misalnya beberapa host dapat menggunakan port yang sama pada perangkat penyimpanan, tetapi mereka hanya dapat melihat target SCSI spesifik dan LUN yang telah mereka tetapkan. Media penyimpanan LUN dapat disediakan, dikompresi dan diduplikasi selama representasi ke host tidak berubah. LUN dapat dimigrasikan diantara perangkat penyimpanan, serta disalin, direplikasi, snapshotted dan berjenjang.

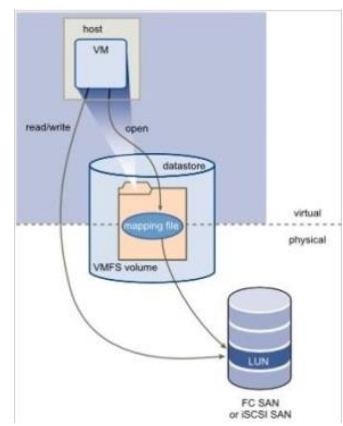

Sumber : [10]

Gambar 1. Logical Unit Number 
d. Storage Area Network

Storage Area Network ( $S A N)$ adalah jenis jaringan area lokal $(L A N)$ yang dirancang untuk menangani transfer data yang besar. Sebuah $S A N$ biasanya mendukung penyimpanan data, pengambilan dan replikasi di jaringan dengan menggunakan server high-end, array beberapa disk dan teknologi interkoneksi Fibre Channel. Teknologi $S A N$ serupa namun berbeda dari teknologi penyimpanan jaringan terpasang (NAS). Istilah $S A N$ dapat merujuk ke jaringan area sistem bukan jaringan area penyimpanan [20].

e. iSCSI (Internet Small Computer System)

iSCSI yang merupakan singkatan dari Internet Small Computer System Interface, bekerja di atas Transport Control Protocol (TCP) dan memungkinkan perintah SCSI untuk dikirim endto-end melalui jaringan area lokal $(L A N)$, jaringan yang luas $(W A N)$ atau Internet. IBM mengembangkan iSCSI sebagai bukti dari konsep pada tahun 1998, dan disajikan draft pertama dari standar iSCSI ke Internet Engineering Task Forre (IETF) pada tahun 2000. Protokol diratifikasi pada tahun 2003 [18].

Adapun jenis - jenis iSCSI antara lain :

1. iSCSITarget

iSCSI target adalah server storage yang menerima perintah iSCSI dari client.

2. iSCSI Initiator

iSCSI ini memungkinkan kita untuk mengakses penyimpanan yang ada di lokasi yang berbeda dari komputer kita.

f. Network Development Life Cycle (NDLC)

Berdasarkan referensi definisi sejumlah model pengembangan sistem yang ada, NDLC merupakan model kunci dibalik proses perancangan jaringan komputer, NDLC merupakan model yang mendefinisikan siklus proses perancangan atau pengembangan suatu sistem jaringan komputer. Seperti model pengembangan sistem jaringan komputer untuk sistem software, NDLC juga mempunyai elemen yang mendefinisikan fase, tahapan, langkah atau mekanisme proses spesifik [4].

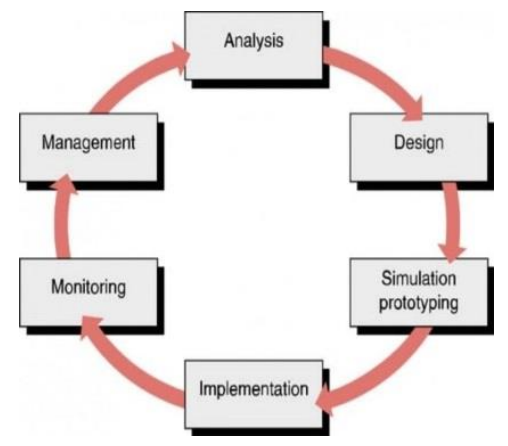

Sumber : [4]

Gambar 2. Network Development Life Cycle (NDLC)

\section{Metodologi}

NDLC mendefinisikan siklus proses yang berupa fase atau tahapan dari mekanisme yang di butuhkan dalam suatu rancangan proses pembangunan atau pengembangan suatu sistem jaringan komputer, terkait dengan penelitian ini, penerapan dari setiap tahap NDLC adalah sebagai berikut:

a. Analisis

Analisis yang menjadikan konsep kebutuhan sistem yang ingin dikembangkan sebagai masukan dan spesifikasi kebutuhan sistem sebagai keluaran. Pada tahap ini dilakukan proses identifikasi konsep sistem . serta mendefinisikan kebutuhan sejumlah elemen atau komponen sistem tersebut, sehingga gambaran umum kebutuhan sistem dapat diketahui.

b. Design

Tahap ini akan dibuat dibentuk dengan merancang topologi sistem jaringan untuk simulasi LAN sebagai representasi sistem produksi (system sebenarnya) dan merancang solusi untuk sistem Berbasis pengambangan Client dan Sever.

c. Simulation Prototyping

Tahap selanjutnya adalah pembuatan prototipe system yang akan dibangun, sebagai simulasi dari implementasi system produksi

d. Implementasi

Pada tahap ini penulis membagi menjadi dua bagian, yaitu: Konfigurasi dan analisis yang meliputi proses instalasi dan konfigurasi terhadap rancangan topologi jaringan dan Drobo SAN PT. Pertiwi Agung, yang akan di rancang atau dikembangkan.

e. Monitoring (Pengawasan)

Tahap ini untuk memastikan apakah Drobo SAN yang sudah dibangun atau dikembangkan, sesuai dengan kebutuhan atau sudah menjawab semua spesifikasi pertanyaan dan permasalahan yang dirumuskan.

f. Management (Pemeliharaan)

Pada tahap ini juga menghasilkkan pengeluaran yang berupa jaminan fleksibilitas dan kemudahan pengelolaan mengenai metode yang cocok dan aman untuk digunakkan pada bertipe Remote Access.

\section{Hasil dan Pembahasan}

\section{A. Perancangan Sistem}

Perancangan sistem dilakukan berdasarkan analisa kebutuhan sistem, pada perancangan sistem ini penulis memaparkan beberapa hal yakni desain dan simulasi yang akan diterapkan. Berikut adalah desain topologi usulan yang dibuat

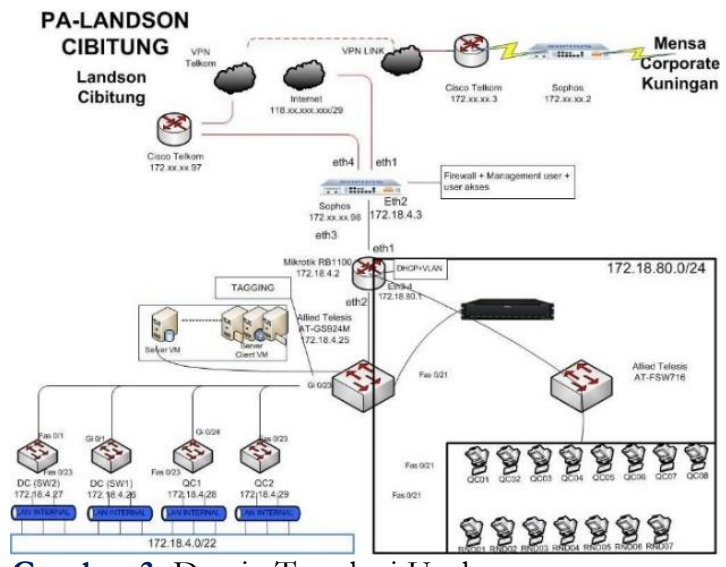

Gambar 3. Desain Topologi Usulan

\section{B. Implementasi sistem}

Implementasi Sistem ini dilakukan berdasarkan hasil 
perancangan sistem diatas yang membutuhkan beberapa konfigurasi pada perangkat keras yang ada. Berikut beberapa Konfigurasi yang penulis usulkan kepada PT. Pertiwi Agung:

1. Mengkonfigurasi perangkat jaringan Shopos sebagai router untuk menghubung PT. Pertiwi Agung dengan Mensa Group

2. Mengoptimalkan perangkat jaringan Mikerotik RB1100 dengan mengkonfigurasi sebagai Firewall, DHCP dan Management User untuk LAN QC-RND Analis PT. Pertiwi Agung

3. Memasang AT-FSW716 (switch-unmanageable) sebagai media distribusi ke Client QC-RND Analis PT.Pertiwi Agung

4. Mengkonfigurasi LUN Drobo Virtual Storage (DroboSAN).

5. Membuat task scheduler untuk membackup Data pada LUN Drobo Virtual Storage ke Local Server.

\section{Hasil dan Pengujian}

Pada tahap ini penulis melampirkan hasil dan pengujian dari beberapa konfigurasi yang dilakukan diatas diantaranya :

a. Hasil Konfigurasi Mikrotik RB1100 DHCP

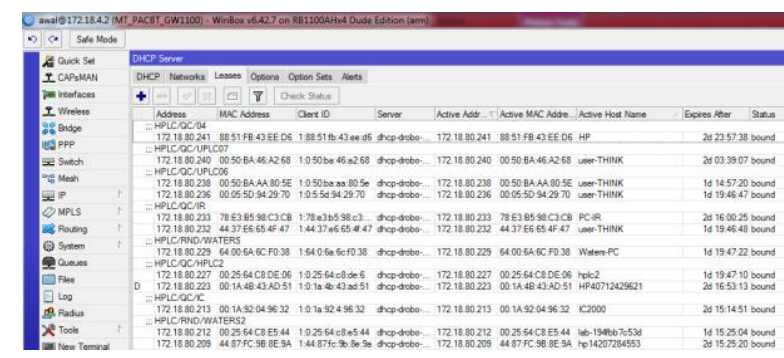

Gambar 4. Hasil Konfigurasi Mikrotik RB1100 DHCP

b. Hasil Pengujian LUN Drobo - Client

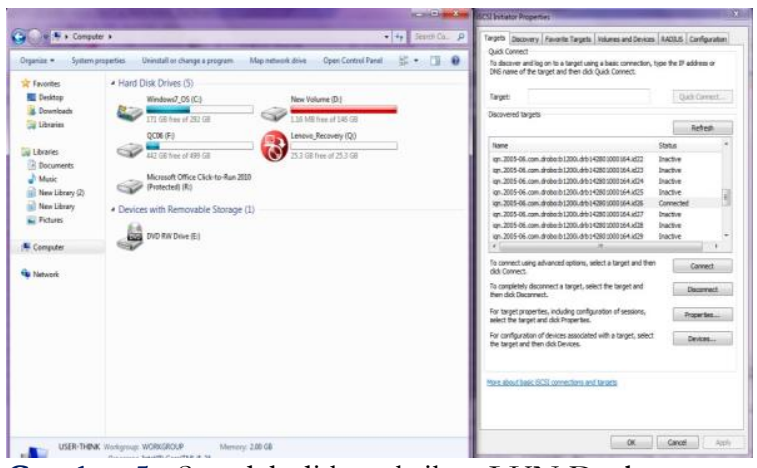

Gambar 5. Sesudah di koneksikan LUN Drobo

c. Hasil pengujian

Berdasarkan pengujian yang dilakukan didapatkan hasil sebagai berikut :

1. DHCP berhasil di lakukan

2. Reopen, Update dan delete analisa produk berhasil dilakukan di LUN DroboSAN

3. Backup date dari external drive ke LUN BroboSAN berhasil dilakukan

4. Block Port Virus berhasil dilakukan

\section{Kesimpulan}

Berdasarkan penelitian yang dilakukan dapat disimpulkan sebagai berikut :

a. Dengan menerapkan Logical Unit Number (LUN) mempu mengatasi permasalahan media penyimpanan sebagai data analisa produk

b. Disamping itu, proses membangun jaringan dengan menerapkan Network Development Life Cycle (NDLC), dapat lebih terstruktur dapal penerapan LUN di seluruh area QC-RND PT. PERTIWI AGUNG

\section{Daftar Pustaka}

[1] Allied Telesis, Inc. https://www.alliedtelesis.com

[2] Cisco Systems. (2017). iSCSI Protocol Concepts and Implementation

[3] Drobo, Inc. https://www.drobo.com

[4] Goldman, James E and Philips Rawles. (2001). Applied Data Communications, A BusinessOriented Approach, Third Edition. West Sussex : John Wiley and Sons

[5] Hu Yoshida. (WHP-091-00, October 1999). "LUN Security Considerations For Storage Area Network - Hitachi Data Systems". ftp://utcc.utoronto.ca/docs/9985V/Hitachi/Whit epapers/WP91\%20San\%20Lun\%2 0Secur.pdf

[6] Jacob Oshins dan Dustin L. Green (US9389895B2, 2016). "Virtual Storage Target Offload Techniques" - Date of Patent : Jul.12,2016

[7] James Long (2006). Storage Networking Protocol Fundamentals. Cisco System, Inc. Cisco Press Indiana Polis USA

[8] Jogiyanto. (2013). Analisis \& Desain Sistem Informasi : Pendekatan tertruktur teori dan praktik aplikasi bisnis. Andy Offset: Yogyakarta.

[9] Jon Tate, Pall Beck, Hector Hugo Ibarra, Shanmuganathan Kumaravel dan Libor Miklas. (2016). Introduction to Storage Area Networks. ISBN 0738441430. United States: Summary of Changes for SG24-5470-06 for Introduction to Storage Area Networks as created or updated on January 14, 2016.

[10] Mikrotik Indonesia, http://www.mikrotik.co.id

[11] Mitchell, Bradley. (2016). "What is Computer Network Storage?".

[12] Muhammad Afad Nawal dan Anton, (2017). "Implementasi Virtual Data Storage Menggunakan OpenFiler dengan Protokol iSCSI pada Kantor Camat Jatinegara Jakarta"

[13] O'Brien, J.A. dan Marakas, G.M. (2011). Management Information Systems. New York: McGraw-Hill.

[14] Priyanka Malviya, (IJCST-V4I4P26, 2016). “A Study Paper on Storage Are Network ProblemSolving Issue" (SHaP- SITI2017)

[15] Raharjo, B. (2016). Mudah Belajar PHP Teknik Penggunaan Fitur-fitur Baru Dalam PHP 5. Bandung : Informatika Bandung.

[16] Reza Yusuf Merdekantara \&, Elkaf Rahmawan Pramudya. (2015). Implementasi dan Analisis Clustering Pada NFS Menggunakan Storage Area 
Network (San) dengan Perbandingan Average I/O Performance.

[17] Sabiq, Ahmad \& Setiadi, Yazid. 2012. Analisa Kinerja Protokol iSCSI Melalui Jaringan Virtual. Jurnal TET, 1(3), 166-173

[18] SearchStorage, 2014. Definition iSCSI (Internet Small Computer System Interface)
http://searchstorage.techtarget.com/definition/iS CSI

[19] Sophos, Inc. https://www.sophos.com/en-us.aspx Tanenbaum. (2003). Computer Networks. WetherAll. USA

[20] Wahyono, Teguh. 2007. Building dan Maintenance PC Server. Jakarta: Elex Media Komputindo 